\title{
UM LEGADO POLÍTICO DA MODERNIDADE CIENTÍFICA: DO ANIMAL RACIONAL ARISTOTÉLICO AO HOMEM-MÁQUINA HOBBESIANO
}

\author{
Luiz Carlos Santos da Silva ${ }^{1}$
}

Resumo: O presente artigo tem por finalidade apresentar como a filosofia natural e política de Thomas Hobbes entende o homem e o cidadão no registro do mecanicismo moderno. Partindo de considerações gerais sobre o pensamento científico na modernidade, o trabalho busca mostrar também como Hobbes criticou a tradição aristotélica da filosofia medieval defendendo um caráter convencional das ciências e da política. No registro de uma modernidade heliocêntrica que racionaliza os mitos e as fábulas da antiguidade clássica para fundamentar o pensamento científico da época, o artigo busca apresentar como os fundamentos da crítica hobbesiana à natureza política do homem passa tanto por uma ressignificação das obras de Aristóteles quanto por uma moderna racionalização dos mitos inaugurada por Francis Bacon. Nesse registro, o trabalho visa fomentar o debate sobre como o legado mecanicista da filosofia moderna parece ser ainda um dos grandes desafios a serem superados pelo pensamento filosófico contemporâneo.

Palavras-chave: soberania, contratualismo, mecanicismo.

\begin{abstract}
This article seeks to present how Thomas Hobbes' natural and political philosophy understands man and the citizen in the register of modern mechanism. Based on general considerations about scientific thinking in modern times, the article also seeks to show how Hobbes criticized the Aristotelian tradition of medieval philosophy, defending a conventional character of science and politics. In the register of a heliocentric modernity that rationalizes the myths and fables of classical antiquity to support scientific thought, the text seeks to present how the foundations of Hobbesian criticism of the political nature of man undergoes a re-signification of Aristotle's works as well as a modern rationalization of myths opened by Francis Bacon. In this register, the article seeks to provoke a debate about how the mechanistic legacy of modern philosophy still seems to be one of the great challenges to be overcome by contemporary philosophical thought.
\end{abstract}

Keyword: Sovereignty, contractualism, mechanism

1 Doutor em filosofia pela Unicamp e professor de filosofia política na UFU. Currículo Lattes: http://lattes.cnpq.br/0036198625835895. 


\section{Hobbes e a modernidade política: uma crítica mecanicista à tradição aristotélica}

É amplamente difundida a ideia de que a modernidade científica, particularmente aquela inaugurada pelas revoluções científicas do século XVII, teria se constituído como uma espécie de movimento intelectual e filosófico caracteristicamente antiaristotélico. Uma vez que as doutrinas políticas e cientificas da tradição medieval se ancoravam sobre as interpretações teológicas da filosofia aristotélica (da Metafísica, da Física e da Política), a modernidade do século XVII entendia que uma crítica à autoridade eclesiástica da igreja romana sobre as ciências, as artes e a política deveria se focar sobretudo em uma crítica à própria filosofia de Aristóteles. Critica essa que procurava purificar e ressignificar a filosofia aristotélica rejeitando o fundamento meramente especulativo ou teórico dos princípios metafísicos da ciência medieval. Nesse registro moderno, Francis Bacon teria apresentado seus ensaios experimentais através de uma ressignificação das obras de Aristóteles que estabelecia o estatuto prático das ciências modernas como uma espécie de purificação da sabedoria dos antigos. O Novum Organum científico apresentado por Bacon mediante uma "crítica dos ídolos" que remontava à antiguidade tanto considerava a Poética como uma parte fundamental da filosofia aristotélica mais sistemática quanto reduzia a autoridade dogmática da Física e da Metafísica diante dos ensaios práticos de uma nova ciência experimental. Galileu, não obstante, com seus Diálogos sobre os dois máximos sistemas de mundo, também teria tentado criticar o geocentrismo aristotélico do medievo com seu heliocentrismo copernicano, que racionalizava a sabedoria dos antigos mediante uma restauração dos mitos gregos e romanos no campo da astronomia. Descartes, destarte, teria também tentado atualizar a sabedoria dos antigos assim como a autoridade ancestral da geometria euclidiana, reivindicadas historicamente pela filosofia medieval de orientação aristotélica. Dentro desse contexto moderno de críticas e ressignificação do pensamento de Aristóteles é que Hobbes parece ter procurado estender o movimento filosófico das modernas ciências da natureza também para as questões relacionadas à política e ao Estado civil. Nesse registro geral, o interesse do presente ensaio consiste em explicitar alguns elementos do moderno legado mitológico, científico e político que a contemporaneidade democrática ou antiautoritária teria como desafio superar filosoficamente.

Nos termos do heliocentrismo moderno de Galileu e do Novum Organum das ciências de 
Bacon, a autoridade da filosofia medieval teria começado a perder sua força discursiva nos campos da religião, da ciência e também da política. Os movimentos contestatórios de Reforma e Contra-reforma católica, latentes na Itália de Copérnico e Galileu, teriam colocado a Inglaterra de Bacon e de Hobbes na vanguarda pela emancipação dos modernos "Estados laicos" frente ao tradicional império teológico-político da igreja romana. É nesse contexto de reformas e ressignificações intelectuais que o pensamento contratualista de Hobbes procura concentrar toda a sua força e potência para criticar as concepções escolásticas acerca de um governo civil fundado sobre a concepção aristotélica do homem como animal político. Com base na concepção de uma natureza política e racional do homem, os doutores da igreja medieval teriam defendido secularmente tanto o geocentrismo astronômico e cientifico quanto o direito divino e hereditário dos reis e dos papas (HOBBES, 1983). A crítica dos modernos, que rejeitavam tanto o geocentrismo quanto a hereditariedade do poder governamental dos padres, nesse registro hobbesiano, teria que passar por uma revisão propositiva tanto dos paradigmas científicos quanto dos princípios políticos da época. Daí o interesse de Hobbes por levar para o campo da filosofia política um moderno método científico que pudesse considerar as ações humanas e a própria constituição do Estado civil no registro do movimento inercial dos autômatos e das máquinas inventadas pelos modernos filósofos da natureza ${ }^{2}$.

Buscando rejeitar a tese essencialista ou ontológica da metafísica aristotélica, Hobbes (2012) procurou ressignificar a importância prática da geometria euclidiana e se esforçou para demonstrar que e como os princípios fundamentais do conhecimento científico moderno deveriam rejeitar em tudo a ontologia das substâncias, essências e outras derivações do verbo ser

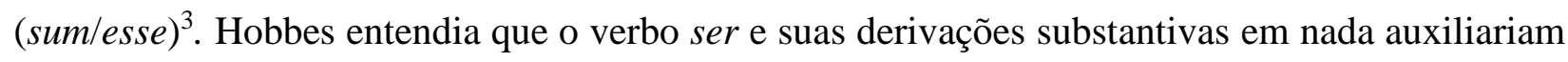
na investigação daquilo que seria mais fundamental nas ciências, quando não atrapalharia. Acontece que, para Hobbes, o ser, representado pela forma conjugada da cópula "_é_" de um juízo categórico do tipo $\mathrm{S}$ é $\mathrm{P}$, consistiria apenas em um verbo de ligação que não se refere à ação

\footnotetext{
${ }^{2}$ Nesse registro histórico da modernidade, vale citar as considerações de Paolo Rossi (Os filósofos e as máquinas) acerca do imaginário moderno em relação aos autômatos desenvolvidos pelas novas tecnologias da época. Ali o historiador trata em detalhes conceituais da relação entre o imaginário mecanicista dos filósofos modernos e o nascimento das ciências na Europa.

${ }^{3}$ Sobre a crítica hobbesiana à ontologia tradicional, ver LEBRUN, G. "Hobbes e a instituição da verdade", in $A$ filosofia e sua história, p. 303.
} 
ou matéria nenhuma no mundo. A cópula (_é_) apenas representaria uma relação ou uma ligação entre um sujeito (S) e seu predicado (P) em um juízo do tipo "Sócrates é homem”, por exemplo. Nesse exemplo, a cópula “_é_” não significa coisa alguma diferente de "Sócrates” e de "homem", mas apenas representa uma relação entre o sujeito e o predicado do juízo, isto é, explicita que Sócrates está contido no universo dos homens ${ }^{4}$. Sob o prisma moderno e utilitarista da filosofia de Hobbes (1983), a ontologia aristotélica e outras investigações filosóficas sobre o ser e seus e suas derivações substantivas (essência, entidade, substância, etc.) seriam não apenas inúteis, mas também prejudiciais às próprias práticas cientificas. Isso porque, além de não ampliarem o conhecimento humano sobre os fatos do mundo, essas teorias sobre o ser ou essências separadas inventariam ontologias filosóficas abstratas e absurdas que só criariam desavenças e desentendimentos de opiniões sobre coisas que estariam para além da experiência humana possível.

No registro antiessencialista da filosofia de Hobbes, a geometria euclidiana e seu método especulativo-prático poderia muito bem demonstrar todos os seus princípios científicos de modo construtivo e sem o auxílio de juízos essenciais ou de cópulas derivadas do verbo ser. Podemos dizer que Hobbes entende a geometria euclidiana como uma espécie de "ética", isto é, como uma ciência ou teoria prescritiva da ação. Para ele as definições da geometria euclidiana seriam como prescrições práticas capazes de orientar tanto o entendimento quanto as ações humanas rumo a um resultado prático e objetivo: a construção de figuras (HOBBES, 2009). Em outras palavras, Hobbes entende que a geometria euclidiana não descreveria objetos naturais, mas, antes, prescreveria modos possíveis de se agir e de proceder no processo de construção de objetos figurados, a exemplo do círculo ou do triângulo. E é nesse registro antiessencialista e prescritivo do método geométrico que Hobbes se esforça para rejeitar, no campo da ética mesmo, a tese aristotélica de que o homem é um animal racional e político por natureza. Para ele, os homens e os outros animais nascem, crescem e morrem segundo as mesmas leis de autoconservação da vida e do movimento, de modo que todas as diferenças fundamentais entre os homens e os outros animais (tanto quanto dos homens entre si) resultariam das ações e dos próprios costumes

\footnotetext{
${ }^{4}$ No segundo livro do De Corpore (2012), Hobbes procura demonstrar como um juízo do tipo S é P poderia ser melhor representado em um diagrama (Venn) onde o sujeito estivesse contido no predicado, dispensando, com isso, qualquer auxilio de cópula, essência ou verbo de ligação substancial.
} 
humanos, não da natureza.

Para Hobbes os homens não nasceriam dotados de racionalidade e nem mesmo naturalmente inclinados à sociedade (1983, p. 30). A filosofia hobbesiana entende que os homens alcançam a racionalidade e buscam o convívio social pacífico apenas pelo costume, pela instrução e pela experiência. Com isso, Hobbes procura de defender a ideia de que, ao contrário da concepção aristotélica, os homens não nascem animais racionais e políticos e nem tampouco o Estado é ou existe por natureza, mas apenas por convenções e contratos (HOBBES, 2002). Sob o prisma geométrico e mecanicista do método hobbesiano, podemos dizer que sua crítica à aristotelia medieval passa por uma ressignificação da metafísica, da física, da retórica, da ética e até mesmo da poética, mas que se foca mesmo em uma rejeição completa dos princípios que fundam a Política de Aristóteles. Hobbes entende que as críticas aos princípios fundamentais da filosofia aristotélica deveriam, antes de tudo, rejeitar a ideia tradicional de que a racionalidade e a política seriam expressões de uma natureza essencial ou substancial do homem. Nesse sentido, o pensamento contratualista moderno inaugurado por Hobbes, apesar de todas as restrições atuais que deveríamos impor à sua concepção absolutista do representante civil ilustrado pelo Leviatã, parece alertar os cidadãos de sua época sobre os perigos do naturalismo político que a tradição eclesiástica utilizava como maneira de ocultar os fundamentos convencionais ou humanos da política e do Estado civil.

\section{Hierarquia natural e racionalidade na constituição da política aristotélica}

Nos primeiros capítulos de sua Política (1999), Aristóteles procura apresentar uma justificação lógica da hierarquia natural que regularia a arquitetônica racional da polis segundo sua origem natural e causal. Para esse filósofo grego, haveria uma hierarquia natural nas próprias coisas do mundo, diferenciadas pela natureza segundo o grau substancial de suas essências e outras derivações do próprio ser (1999, p.147). No registro da Metafísica, por exemplo, as substâncias puras ou simples portariam consigo um grau de excelência e perfeição superior às substâncias misturadas ou compostas. Esse mesmo pensamento, expresso na Metafísica de Aristóteles no registro de uma hierarquia substancial entre os graus do ser (ARISTÓTELES, 2002), parece também regular sistematicamente as considerações do filósofo na Física, na Ética e na Política. Regulado pela ideia fixa de um "lugar natural" determinado segundo o modo de ser 
de cada coisa, Aristóteles procurou configurar sua concepção hierárquica da natureza de modo a poder aplicá-la na investigação dos homens ou dos cidadãos. Ao tratar da constituição da polis na sua Política, Aristóteles defende a existência de uma hierarquia natural de uns homens sobre os outros a partir de um a priori hierárquico do próprio ser em si, tratado na Metafísica. Ancorado naqueles princípios metafísicos que caracterizam, na Ética, o modelo de homem mais excelente e livre segundo diferentes graus de racionalidade, Aristóteles desenvolve suas considerações sobre a formação do governo civil na Política (1999, p. 148) defendendo que, por desígnio mesmo do ser ou da natureza, alguns poucos indivíduos teriam nascido aptos para comandar e os todos outros para serem comandados.

Avançando em suas considerações políticas a partir dessa concepção metafísica de uma hierarquia natural do ser no mundo, Aristóteles apresenta na Metafísica (2002) uma espécie de pirâmide conceitual de onde se poderia extrair, euclidianamente falando, uma concepção hierárquica do ser e da natureza capaz de ser aplica a todas as demais áreas de investigação filosófica, inclusive ao homem. É com base nessa concepção metafísica de uma hierarquia natural do ser nas coisas do mundo que Aristóteles procura justificar na Política as diferenças entre humanos e animais, homens e mulheres, senhores e escravos (1999, p.149). Diferenças essas de ser, de natureza ou de essências que regulam substancialmente as definições aristotélicas do "lugar natural" dos homens, mulheres, dos filhos e dos escravos dentro de uma pirâmide social hierárquica que coloca o animal racional exaltado (pater familias) no topo mais alto do podium social.

Lembremos que, para a filosofia aristotélica, os homens seriam animais racionais por natureza. Todavia, Aristóteles entende que, apesar desse legado comum ser um atributo da natureza, haveria uma gradação de racionalidade entre os indivíduos, estabelecida pela própria natureza humana e pela diferença de graus do ser, essência ou substância dos corpos materiais. Assim, embora todos os homens livres, escravos e mulheres possam ser considerados "seres racionais" por natureza, Aristóteles defende que apenas os primeiros (homens livres) poderiam alcançar o pleno uso dessa faculdade, em detrimento dos demais homens e mulheres. No registro de uma natureza hierárquica, tabulada segundo graus de pureza e essência, Aristóteles procura justificar na Política a relação de subordinação do escravo frente ao senhor com base em diferentes graus de racionalidade: o senhor ou pai de família estaria naturalmente habilitado a 
comandar o escravo e a mulher com seus filhos pelo fato de ser supostamente mais racional do que os outros, segundo os desígnios da própria natureza ou do ser. Nesse registro geral da hierarquia natural do ser ou da substancia em Aristóteles, sua Política poderia até mesmo ser entendida como uma espécie de teoria do "lugar natural" dos homens, das mulheres e dos escravos dentro da pólis ou cidade-Estado.

Por essa razão ancestral de uma hierarquia natural hereditária, a Política de Aristóteles faz citação direta à sabedoria dos antigos poetas (Homero e Hesíodo, respectivamente) quando defende que "os gregos tinham o direito de dominar os bárbaros" e que, no pleno uso de sua racionalidade, um homem livre deveria possuir "a casa, depois a mulher e o boi para o arado" (ARISTÓTELES, 1999, p. 144-5). Nesse registro aristotélico da hierarquia política, somente os homens que conquistassem propriedade e escravos (esposa e prole) deveriam ser considerados indivíduos livres e, por essa razão, aptos a conduzir racionalmente a si mesmos e designados a comandar os demais. A estrutura piramidal que caracteriza a arquitetônica da Política aristotélica se regula por uma concepção hierárquica de natureza ou do ser que passa pela Ética, pela Física e remonta mesmo à Metafísica. Aristóteles entende que aquilo que está no princípio de uma coisa deve também estar no seu fim (2002), de modo que a finalidade de uma coisa deve corresponder à essência ou natureza constitutiva dessa coisa encerrada em si. Nesse registro metafísico, o filósofo justifica as diferenças de poder na estrutura social da polis defendendo insistentemente a tese finalista que isso seria um desígnio da própria natureza do ser considerado em relação aos homens e cidadãos. Para exemplificar, cito o primeiro livro da Política:

Portanto, a cidade-Estado é uma forma natural de associação, assim como eram as associações primitivas das quais ela se originou. A cidade-Estado é a associação resultante daquelas outras, e sua natureza é, por si, uma finalidade; porque chamamos natureza de um objeto o produto final do processo de aperfeiçoamento desse objeto, seja ele homem, cavalo, família ou qualquer outra coisa que tenha existência.(...) Por conseguinte, é evidente que o Estado é uma criação da natureza e que o homem é, por natureza, um animal político. E aquele que por natureza, e não por mero acidente, não tem cidade, nem Estado, ou é muito mau ou muito bom, ou sub-humano ou super-humano como o guerreiro insano condenado, nas palavras de Homero, como alguém 'sem família, sem lei, sem lar'; porque uma pessoa assim, por natureza amante da guerra, é um não colaborador, como uma peça isolada num jogo de damas. (ARISTÓTELES, 1999, p. 146).

Estabelecidos metafisicamente os "lugares naturais" dos indivíduos dentro da 
hierarquia social da polís, Aristóteles procura explicar como teria se dado, por natureza, a constituição da cidade-Estado: os indivíduos, masculino e feminino, teriam se juntado para formar a família. A família, assim, seria o princípio e a matéria causal da vida política em Aristóteles, sendo considerada a primeira forma natural de sociedade, a partir da qual a própria polis teria se originado. Uma vez considerado o pai ou proprietário (pater familias) como o ser mais racional dentre os homens, ele deveria naturalmente comandar a mulher, os filhos e os escravos tal como os bois para o arado. Considerando a figura do pai como sendo o indivíduo mais racional da família exatamente por ser senhor e proprietário, o formato político aristotélico, desenvolvido naturalmente a partir desse princípio, conduz inevitavelmente a um modelo de governo patriarcal, isto é, a um tipo de política de proprietários e de senhores de escravos (oligarquia ou aristocracia). E assim como cada coisa teria seu lugar natural dentro do pensamento metafísico e cosmológico de Aristóteles, cada tipo de indivíduo teria seu "lugar natural" dentro da hierarquia social: senhores para o comando, esposas para a procriação, escravos para o trabalho manual e bois para o arado.

A partir desse modelo naturalista de hierarquia familiar, Aristóteles justifica a finalidade da constituição natural de tribos, aldeias e comunidades humanas como tendo sempre a pólis como finalidade e bem supremo. O fim ou finalidade da família seria a realização de uma essência política do ser humano, posta como um desígnio inescapável da natureza desde o princípio da vida no homem. Sob esse prisma aristotélico, podia-se dizer que todos os povos e indivíduos que costumavam viver de modo nômade ou selvagem, ou seja, não constituindo cidades hierárquicas, deveriam ser considerados como seres inferiores e/ou menos racionais; donde se justificaria a guerra e a escravização desses outros povos e indivíduos não politizados ou civilizados, tendo em vista o suposto progresso, benefício ou sobrevivência deles próprios.

Uma vez que, para Aristóteles, o todo existe necessariamente antes das partes (2002), é preciso considerar, analiticamente, que o animal político, sendo a matéria constitutiva da polis, é, antes de tudo, o animal racional. Ou ainda, os senhores de família, artífices naturais dessa mesma polis, são, ao mesmo tempo, seres racionais e animais políticos; posto que estão tanto no princípio quanto no fim desse processo de constituição política. Aristóteles entende que a polis é o fim da natureza humana, isto é, a realização da essência ou da natureza do ser humano como animal racional. É na polis que esses homens exercem o seu logos, isto é, a razão de maneira 
mais excelente e plena (1999, p.143). A natureza teria dotado os homens com a faculdade da razão, expressa no comportamento humano sobretudo através da linguagem: o homem é um animal que fala de tal e de tal modo, isto é, de maneira ordenada e representativa. Acontece que o homem aristotélico só poderia de fato realizar sua essência ou natureza racional se tornando um cidadão, isto é, constituindo racionalmente a polis: a vida racional plena em Aristóteles é a vida política. Contudo, embora as mulheres, os filhos e os escravos sejam considerados a base dessa pirâmide social, somente alguns poucos homens naturalmente "mais racionais" é que poderiam realizar esse suposto uso pleno da razão. Sob esse prisma do Estado constituído pela natureza racional do homem, podemos dizer que a polis aristotélica não constituiria de fato um fim da natureza humana, porém um meio de sua realização. Em outras palavras, a política em Aristóteles poderia ser entendida como um modo através do qual o homem alcança o pleno uso de sua racionalidade, uma vez instaurada a hierarquia social que colocaria cada indivíduo em seu lugar natural e os indivíduos mais racionais no topo dessa pirâmide social.

No registro de uma realização do ser ou de uma natureza humana em Aristóteles, o animal político seria o produto final do processo de aperfeiçoamento do animal racional por natureza, a saber, o cidadão. A política de Aristóteles, sob esse prisma, poderia ser entendida como um processo da natureza que transformaria homens em cidadãos, de modo as pessoas que não se submetessem a um regime político hierárquico não deveriam sequer ser consideradas seres humanos ou racionais. Assim, o mesmo indivíduo, proprietário e pai de família, torna-se o cidadão, posto como princípio e fim da política, ou seja, matéria e artífice da pólís. Em outras palavras, podemos dizer que, em termos de uma teleologia aristotélica, os homens que se encontram à testa de uma cidade-Estado ou de um governo político estariam no fim desse processo justamente porque estiveram no seu começo, ou seja, "o todo antes das partes". Esse tipo de raciocínio, que perpassa questões relacionadas à metafísica, à física, à ética e remonta à política de Aristóteles, parece ter mesmo servido de princípio para os doutores da igreja romana medieval justificarem suas próprias superioridades em relação aos fiéis, seus súditos (HOBBES, 1983, p. 384). Apoiados sobre os pilares dessa concepção hierárquica da natureza em Aristóteles, as autoridades eclesiásticas do medievo teriam procurado justificar a soberania hereditária dos patriarcas, reis e senhores (papas) no registro de uma teoria filosófica do reino dos céus na terra dos homens. E parece ser nesse registro de uma oposição à tradição medieval do pensamento 
hierárquico que a contemporaneidade democrática deveria voltar suas reflexões filosóficas para uma crítica ao naturalismo político pregado pelos discursos teológicos e pela suposta neutralidade da razão científica. A finalidade dessa critica seria a responsabilização do próprio homem, e não mais da natureza ou de Deus, pelas causas e pelas consequências das ações políticas de um Estado civil do qual o próprio homem seria tanto o artífice quanto a matéria.

\section{O homem-máquina hobbesiano e o Estado civil soberano}

A modernidade cientifica acusou a tradição medieval de fundar suas teorias e justificações teológicas, científicas e políticas sobre as bases metafísicas da filosofia de Aristóteles; particularmente o geocentrismo e o direito divino dos reis. Adepto desse movimento moderno de contestação e crítica à autoridade papal e eclesiástica da tradicional igreja romana, Hobbes se esforçou para rejeitar os fundamentos da política aristotélica, com o intuito de fundar as bases do moderno Estado laico sobre outros paradigmas diversos: a geometria euclidiana. Ao contrário da política de Aristóteles, que considerava o homem sob o prisma da autonomia e da razão natural, Hobbes entendia o homem como uma espécie de máquina, movida e comovida por suas paixões mais irracionais: o medo e a esperança. O homem hobbesiano não é considerado um ser racional por natureza, por isso tanto a política quanto as ciências em Hobbes dependem sempre da instrução, da educação e dos costumes, não da revelação divina ou da genialidade natural de alguns poucos homens mais sábios ou eruditos do que outros de nascença. O homem hobbesiano é uma criatura, isto é, um artefato criado pelas mãos de um "Deus-pai", assim como o cidadão seria uma espécie de "manufatura" do Estado civil, isto é, da "pátria". Por conta disso, o homem e o cidadão deveriam ser considerados como máquinas e autômatos que, assim como as demais criaturas vivas, teriam sido programados por Deus e pelo Estado civil para se auto conservarem e procriarem com esse legado hereditário à prole. Sob esse prisma, por mais que a modernidade hobbesiana tenha se esforçado para rejeitar a hierarquia do naturalismo teológico na política medieval, sua proposta mecanicista para a política parece resultar na transformação dos homens e dos cidadãos em peças e engrenagem da máquina soberana de um Estado civil autômato: o Leviatã.

O homem é considerado por Hobbes como uma máquina programada naturalmente para nascer, crescer, reproduzir-se e morrer dentro de seu devido tempo. Sob esse prisma, 
podemos dizer que a concepção de homem-máquina hobbesiano seria o resultado de uma filosofia da natureza que toma como princípio e fim da conduta humana a autoconservação do movimento da matéria: a geometria ou a mecânica moderna ${ }^{5}$. A vida é definida por Hobbes como movimento, de modo que o objetivo da conduta humana rumo à felicidade se caracterizaria como uma incessante busca pela autoconservação de si e do movimento vital dos homens. O mecanicismo ético hobbesiano é ilustrado pela metáfora dos relógios de pêndulo, onde o movimento das engrenagens, embora contínuo e ininterrupto, não teria por finalidade outra coisa senão a conservação do próprio movimento dos ponteiros que marcam as horas (HOBBES, 2002, p. 13). Nesse registro geométrico e mecanicista, a filosofia hobbesiana entende tanto o homem natural quanto o Estado civil sob o prisma de uma cosmologia moderna que regularia todas as coisas no universo cada qual ao seu tempo: o princípio de autoconservação do movimento da matéria.

Segundo a concepção da modernidade mecanicista de Hobbes, tudo no mundo e na natureza seria regido pelas leis causais do movimento. E a causa de uma coisa em movimento deve ser sempre alguma outra coisa também em movimento, nunca o repouso. Desse modo, não seria necessário ou mesmo conveniente para as ciências investigar os fenômenos do movimento a partir de formas fixas, essências imutáveis ou substâncias isentas de todo movimento e mudança. Se tratando dos fenômenos do movimento tudo seria aparência, incompletude constante e perpétua mudança. Por isso a imutabilidade de formas fixas e essências estruturais atrapalhariam bastante a interpretação prática da natureza e de tudo aquilo que muda no mundo, a saber, os próprios fenômenos naturais ou políticos. Essa concepção hobbesiana acerca do princípio de autoconservação que regula a consideração da conduta dos homens parece estar mesmo ancorada sobre a moderna ideia heliocêntrica (copernicana/galileana) de que tudo no cosmos está em constante movimento inercial, nunca em repouso. E assim como não haveria um fim último ou causa final do movimento (a não ser a própria conservação do movimento) também não haveria uma natureza do ser humano a se realizar segundo os desígnios de uma racionalidade política que

\footnotetext{
${ }^{5}$ Hobbes entende a geometria como uma espécie de ciência do movimento análoga à mecânica moderna. Em outras palavras, a geometria seria um tipo de conhecimento prescritivo capaz de orientar o entendimento e a ação humana no processo de construção de corpos e objetos (linhas, ângulos e figuras) a partir do simples movimento de um único ponto da matéria. Sobre esse assunto, publiquei um artigo intitulado: A geometria das paixões humanas na filosofia do poder de Thomas Hobbes. (Revista Trilhas filosóficas, v.8, n.1, Ed. UERN, Natal, 2015).
} 
prescreveria a felicidade humana como o repouso de um espírito satisfeito e feliz na polis. A vida consiste em movimento e, para Hobbes, a felicidade humana se reduziria apenas à conservação constante desse movimento que se exprime nas ações, desejos e vontades.

Hobbes parte do princípio moderno de que tudo o que existe de fato na natureza são apenas os corpos em movimento ${ }^{6}$. Por isso as ideias, pensamentos, imaginações, sensações e desejos seriam apenas efeitos da matéria em movimento que atua sobre o corpo e os sentidos humanos, ou seja, fenômenos ou manifestações do simples movimento. Se a vida é também movimento (circulação, respiração, articulação, etc.), então o desejo que os objetos externos causam e produzem no interior das mentes e dos corações humanos não poderiam encontrar seu fim ou repouso senão na morte do homem, que é a ausência do movimento vital. E assim como não haveria a felicidade humana entendida como o repouso de um espírito satisfeito na polis, Hobbes entende que a política e o Estado civil não poderiam ser pensados como a realização natural ou a causa final de uma suposta essência imutável do animal racional e político de Aristóteles. O Estado civil e os cidadãos, para Hobbes, existiriam apenas por convenção e por artifício, nunca por natureza.

Ao contrário de Aristóteles, Hobbes entende que os homens não nascem seres racionais, mas que podem e devem ser educados para a racionalidade; cujos usos eles podem vir a fazer corretamente apenas quando se tornam adultos (1983, p. 31). Em outras palavras, Hobbes entende que as crianças nasceriam aptas apenas a imitar o comportamento daqueles que as educam: se são educadas por uma matilha de lobos vão aprender a uivar, caçar e a se comportar como animais selvagens. Mas, se são educadas por uma pátria bem constituída (Estado civil soberano), os homens podem aprender a falar racionalmente e se tornam cidadãos obedientes, ou seja, animais domesticados. Todas essas diferenças comportamentais entre o homem e os lobos não derivariam necessariamente da natureza, porém dos costumes que podem ou não formar a

\footnotetext{
${ }^{6}$ No capítulo 9 do Leviatã, por exemplo, ao apresentar seu gráfico de distribuição das ciências, Hobbes apresenta a especificidade de cada disciplina do conhecimento humano segundo derivações dos acidentes dos corpos em movimento. A partir de uma diferença básica entre corpos naturais e corpos artificiais segundo o mesmo princípio de autoconservação do movimento, Hobbes estabelece dois tipos de poderes que vão regular tanto a filosofia natural quanto a política. Conhecimento é poder e esse poder se aplica ao homem na mesma proporção em que se aplica à natureza.
} 
personalidade dos indivíduos como lobos selvagens ou como cidadãos domesticados ${ }^{7}$. A natureza, segundo Hobbes, teria criado os seres humanos submetidos igualmente às mesmas leis da autoconservação do movimento, de modo que toda e qualquer superioridade entre homens e mulheres ou senhores e escravos resultaria fundamentalmente dos costumes e dos hábitos próprios homens, não da natureza.

Hobbes entende que a racionalidade, isto é, o raciocínio ou o cálculo com palavras (ratiotinatio e não ratio), não seria uma habilidade inata do homem, mas uma capacidade adquirida através da educação, do costume e da experiência (1983, p. 30). A racionalidade que Hobbes considera como sendo caraterística das ciências não seria propriamente aquela capacidade natural de calcular (ratio), que os homens também compartilhariam com os outros animais. Muitos seres vivos são inteligentes o bastante para calcularem os meios para sua sobrevivência e nem por isso são considerados seres racionais ou dotados de ciência. A razão científica em Hobbes consiste naquele uso lógico ou ordenado que os homens fazem com linguagem nos cálculos com signos e palavras (ratiotinatio). O interesse da filosofia hobbesiana se volta mais para os usos da razão do que para a razão em si, considerando o exercício dessa faculdade ou habilidade em ato, não apenas em potência. Hobbes entende que o homem nasceria com uma capacidade natural de calcular análoga a de quaisquer outros animais dotados de inteligência. A racionalidade que diferenciaria os homens dos outros animais não residiria em uma suposta essência humana racional, porém nos usos que os homens fazem disso para se expressar e se comunicar uns com os outros. Analogamente aos outros animais, o homem hobbesiano seria dotado de uma razão natural calculadora que prescreveria em tudo a autoconservação do indivíduo como regra básica da conduta. Nesse registro, todos os usos dessa faculdade inata do homem deveriam ser considerados como meios para a realização dos fins postos pelo desejo de autoconservação. Ao tratar da razão cientifica, Hobbes está considerando a racionalidade humana apenas no registro de seu uso regulado, isto é, como instrumento simbólico

\footnotetext{
${ }^{7} \mathrm{Na}$ epistola dedicatória do De Cive ou Do cidadão, Hobbes anuncia sua famosa tese de que "o homem é o lobo do próprio homem" (2002, p. 3). Essa menção faz referência direta à ideia de que o Estado civil soberano teria sido um legado da mitológica figura de Rômulo, o fundador da cidade que leva o seu nome: Roma. Sobre esse assunto, publiquei um artigo intitulado: Tragédia na modernidade: o Leviatã hobbesiano como metáfora de representação política. (Especiaria: caderno de ciências humanas". v. 16, n. 28, Ed. UEBA, Ilhéus, 2016.)
} 
de representação compartilhada. Essa razão instrumental não estaria interessada em estabelecer fins últimos para a conduta natural dos homens, mas, antes, calcular os meios de realização dos desejos e da vontade postos inicialmente pela natureza como princípio de autoconservação dos corpos em geral.

A filosofia hobbesiana, portanto, parece não se interessar tanto por uma consideração da razão (ratio) como potencialidade humana em si, porém como ato ou ação, isto é, como raciocínio (ratiotinatio). A razão em Hobbes é investigada segundo seus usos, por isso ela é considerada no registro de um utilitarismo que entende essa faculdade natural como um instrumento das paixões, não o contrário. Se as ações que levam um agente qualquer à autoconservação de si fosse um ato racional (deliberado), então não seria possível entender porque, na busca pela autoconservação e pela segurança dos indivíduos, os homens acabam fomentando a guerra entre si; o que é manifestamente contrário à autoconservação da vida de quem quer que seja. Eis o paradoxo da filosofia hobbesiana: buscar a paz através da guerra parece ser contrário à razão de qualquer um que busque esse fim, porém estaria em conformidade ao princípio de autoconservação da vida que rege os desejos e a vontade dos homens. O conhecimento humano característico das ciências e da política pressupõe sempre o conhecimento das causas da guerra e da paz, que são as paixões e as ações humanas. Hobbes declara que, na maior parte das vezes, os homens agem contrários à razão na busca pela autoconservação da vida através da subjugação da natureza, da antecipação e do confronto bélico. E isso se explicaria não por uma suposta hostilidade inata nos homens, mas pelo costume legado de uma cultura bélica e conflituosa que vê tanto a natureza quanto os próprios homens como potenciais inimigos. Para Hobbes, portanto, os homens não nascem seres racionais ou animais políticos, mas se tornam racionais e políticos através da instrução e do costume. Para exemplificar a concepção hobbesiana de razão, cito o capítulo 5 do Leviatã:

As crianças, portanto, não são dotadas de nenhuma razão até que atinjam o uso da linguagem, mas são denominadas seres racionais devido à aparente possibilidade de terem o uso da razão na sua devida altura. E a maior parte dos homens, embora tenham o uso da razão em certos casos, como em contar até certo grau, contudo serve-lhes pouco na vida comum, na qual se governam, uns melhor, outros pior, segundo suas diferentes experiências, rapidez de memória e inclinações para vários fins, mas especialmente segundo a boa ou a má fortuna, e os erros de uns em relação aos outros" (HOBBES, 1980, p. 30 ) 
Vimos que Hobbes entende que a razão natural dos homens como um instrumento das paixões. Instrumento esse que operaria como mero calculador dos meios que levam aos fins postos pela vontade e pelo desejo, não o contrário. Os movimentos voluntários, isto é, aqueles que passam pela deliberação da vontade, diz Hobbes, em nada dependem da racionalidade para moverem, comoverem ou locomoverem os agentes. Um pássaro, um peixe ou qualquer outro animal vivo poderia agir deliberadamente com vistas à sua autoconservação e, nem por isso, deveriam ser chamados "seres racionais" ". As ações deliberadas que regulam o comportamento dos agentes são consideradas movimentos voluntários que não dependem da razão para serem executadas, mas apenas da experiência, do desejo e, evidentemente, da vontade. Nesse registro mecanicista da filosofia hobbesiana, a constituição do Estado civil e da própria política estatal deveria, no processo de investigação da conduta dos homens e dos cidadãos, levar em conta mais as paixões e a vontade dos homens do que a razão e os conceitos fillosóficos. Isso porque, as primeiras paixões, ao contrário da razão ou do cálculo, seriam atributos comuns a todos os homens e capazes de regular igualmente as ações deles desde o nascimento até a morte.

O Estado civil hobbesiano, enquanto um poder constituído pelos homens e para os homens, se funda sobre as paixões e a experiência dos indivíduos criados em uma cultura de medo e de subordinação doméstica, a saber, os filhos pródigos da madre igreja romana (HOBBES, 1983). A razão civil é considerada produto do Estado, assim como também seria o animal racional ou o cidadão. O cidadão hobbesiano não é considerado cria da natureza, mas sim produto da vida humana em sociedade, isto é, do Estado. Não é sem razão, portanto, que Hobbes defenda a obrigatoriedade do ensino público por parte do Estado civil soberano, tanto quanto o controle da produção intelectual e das ciências desenvolvidas pelas universidades e instituições de pesquisa ${ }^{9}$. A racionalidade, bem como as ciências e a filosofia, seria um tipo de instrumento

\footnotetext{
${ }^{8}$ Vale destacar aqui que o princípio de autoconservação da vida em Hobbes não constitui um direito natural exclusivo do homem, mas se estende da natureza para todos os corpos vivos ou seres animados. A tradição liberal da política costuma tratar equivocadamente o princípio de autoconservação dos indivíduos em Hobbes no registro dos direitos naturais e humanos ditados pela racionalidade. Acontece que, ao contrário dessas interpretações liberais do absolutismo hobbesiano, nem os direitos efetivos do homem e nem mesmo a racionalidade em Hobbes existem por natureza, mas apenas por convenção e costume. Ver o Leviatã I, 5 (1983, p. 28-30).

${ }^{9}$ No livro IV do Leviatã, bem como em diversas passagens do De Corpore, Hobbes critica as "trevas das vãs filosofias" afirmando que o Estado deveria regular as doutrinas de fundamento metafisico e religioso porque elas seriam infundadas e propensas aos conflitos de opinião.
} 
político que deveria ser fomentado e regulado pela própria "razão de Estado" do soberano. Se a razão natural dos homens calcula os meios que prescrevem os fins do comportamento humano de autoconservação, então o controle da racionalidade dos homens resultaria também no controle de suas paixões e opiniões, isto é, do seu comportamento. A racionalização dos mitos ancestrais na modernidade científica, sob esse prisma, poderia muito bem auxiliar como um projeto criptografado de controle das paixões e produção da opinião pública. E o Leviatã hobbesiano, como uma espécie de racionalização do mito do Estado, parece ser a ilustração maquinal mais clara desse projeto científico moderno: as ciências como um gigantesco artificio de engenharia social.

Ao contrário de Aristóteles, Hobbes entende que toda comunidade ou associação é sempre uma convenção artificial e não natural. Nesse sentido, Hobbes entende a família, que seria a primeira forma de associação ou de comunidade humana, como a mais fundamental convenção ou instituição artificial criada pelos homens, artífices do Estado. A família em Hobbes, enquanto o primeiro e mais fundamental artificio social dos homens, teria servido de modelo e base para a constituição de um Estado civil também convencional ou artificial, isto é, de uma máquina capaz de produzir ou reproduzir sua própria prole de cidadãos obedientes ${ }^{10}$. Hobbes entende os modos de organização social dos inúmeros povos do mundo como costumes tão antigos e diversos que seria praticamente impossível determinar uma forma fixa e imutável da política, a partir de uma suposta natureza política dos homens em geral. O conhecimento das causas fundamentais da política dependeria do conhecimento dos movimentos e dos poderes de seus elementos constitutivos, isto é, de sua matéria e de seus artífices: ambos o homem. O Estado civil moderno, isto é, a civitas, deveria ser constituída como uma pátria soberana simplesmente porque, segundo Hobbes, teriam sido os "pater familias" os primeiros fundadores dessa instituição: um homem artificial civil criado à imagem e semelhança de seus próprios artífices (HOBBES,1983, p. 5). A hierarquia entre os homens, a formação da família e a constituição do

\footnotetext{
${ }^{10}$ Ao tratar do domínio despótico e paterno, no Leviatã, II, 23 (1983, p.125) Hobbes afirma que toda grande família que não pertença a um Estado civil soberano poder ser considerada uma pequena monarquia. Nesse registro, podemos dizer que, se existe uma "máquina ancestral" produtora do homem-máquina hobbesiano essa "máquina ancestral" só pode ser a família. A família tradicional, sob o prisma hobbesiano, poderia ser considerada uma espécie autômato original, capaz de produzir e reproduzir um costume hereditário que desembocaria, por convenção e artificio, na constituição de um Estado civil também maquinal.
} 
Estado civil em Hobbes, vale sempre ressaltar, existiriam tão somente por convenção e artifício, nunca por natureza. E por mais que essa proposta contratualista de Hobbes possibilite uma perspectiva humanística ou antropomórfica sobre a fundação do Estado civil (coisa que o naturalismo teológico do medievo jamais permitiria), o modelo maquinal, hereditário e soberano da política hobbesiana parece ter se tornado um dos maiores desafios a serem superados pelo pensamento democrático ou antiautoritário contemporâneo. Pois, no registro do Leviatã hobbesiano, o exercício do poder governamental pelas mãos de muitos homens pode propiciar um cenário de disputa e competição entre as partes interessadas no governo. Diante desse hipotético cenário de competição entre os homens pelo poder e pela autoridade, comparável ao estado de natureza hobbesiano, a figura soberana do Leviatã pode ressurgir das cinzas do tempo no eterno retorno do progresso tecnológico, que atualiza o mito do homem-máquina moderno como artífice permanente do Estado civil sempre atualizado.

\section{O eterno retorno da modernidade: método científico e racionalização dos mitos.}

Acredito que superar o legado maquinal do contratualismo soberano de Hobbes, mas sem recair no antigo naturalismo teológico do medievalismo aristotélico, seja um dos principais desafios do pensamento filosófico antiautoritário da contemporaneidade. Pois, ainda hoje reverbera fortemente os ecos do mecanicismo político hobbesiano nos atuais gerencialismo da maquinal estatal capitalista. O simples fato de os economistas contemporâneos ainda entenderem o Estado civil como uma espécie de máquina ou autômato revela esse fundamento filosófico de uma modernidade hobbesiana que articula ciência e política no mesmo registro do poder e da autoridade. Sob o prisma de uma moderna racionalização da sabedoria dos antigos, podemos dizer que o pensamento político de Hobbes deve ser entendido no registro das grandes revoluções científicas daquele período; particularmente no tocante à ressignificação crítica da filosofia de Aristóteles. Assim, por mais que o mecanicismo moderno possa ter sido crítico em relação à metafísica do medievo, a própria modernidade parece ter se fundado sobre uma racionalização criptografada dos princípios lógicos e representativos da filosofia aristotélica mais prática: a arte poética $^{11}$. A modernidade cientifica na qual Hobbes se colocou parece ter resultado de uma ${ }^{11}$ Na Poética, Aristóteles se dedica a demonstrar que a tragédia, considerada o melhor modelo de arte poética, teria
como causa a imitação, como efeito a síntese e como objetivo o reconhecimento. Defendendo a tese de que a tragédia 
revisão ordenada da filosofia aristotélica onde a Poética teria ganhando, no registro de uma "lógica da representação", um estatuto prático substancialmente superior à própria Metafísica ${ }^{12}$. Os mitos e fábulas ancestrais parecem ter regulado a matéria de um imaginário filosófico moderno onde o método geométrico teria operado mediante uma racionalização da sabedoria dos antigos que fundava conceitos e representações das ideias cientificas, a exemplo do próprio heliocentrismo de Copérnico e Galileu. Se a ontologia aristotélica se interessava por tratar a substância e a razão como coisas em si mesmas, o mecanicismo moderno, por outro lado, buscava tratar os fenômenos do movimento e os usos da racionalidade segundo representações imagéticas e símbolos da linguagem humana articulada: a geometria e suas figuras. A imagem do próprio Leviatã, como racionalização de um mito ancestral capaz de representar o Estado civil moderno, é uma ilustração muito clara dessa atualização metodológica da potência mitológica ou poética atrelada à geometria. Trata-se de um moderno tipo de "filosofia da representação" que, ao envolver teoria e prática no processo de atualização da potência trágica dos mitos, poderia servir de inspiração metodológica para fundar tanto as ciências naturais quanto a política na modernidade.

Sob esse prisma geral da modernidade, podemos dizer que, se, por um lado, Hobbes procurou rejeitar a tradição aristotélica do medievo criticando obras como a Metafísica, a Física e a Política, por outro lado, ele parece ter colocado a Poética como fundamento de uma outra lógica interpretativa de Aristóteles: uma lógica geral da representação ${ }^{13}$. No registro de uma "liberdade poética" das interpretações modernas sobre a filosofia de Aristóteles, os filósofos parecem ter encontrado na Poética um modelo filosófico de representação que poderia operar como uma espécie de racionalização dos mitos e das fábulas ancestrais de modo prático e prescritivo: purificação, síntese e reconhecimento no processo de redução ao essencial e

seria a imitação de uma ação completa e elevada (1999, p. 57). Aristóteles afirma que esse método prático operaria com uma redução do mito ancestral aos seus elementos essenciais, tendo em vista a purificação das paixões humanas que despertem o reconhecimento do público espectador com os atos e personagens narrados.

${ }^{12} \mathrm{O}$ modo como a representação e a imitação são tratadas pela Poética de Aristóteles parece ter se tornado matéria e conteúdo do método filosófico na modernidade científica em Bacon, Galileu, Descartes, Hobbes entre outros.

${ }^{13}$ A relação entre geometria e arte poética parece ser mais do que manifesta, uma vez que os poemas são metrificados por versos que remontam à antiga cultura daqueles povos que mediam e araram a terra mediante princípios geométricos. 
atualização da cultura dos antigos. A racionalização dos mitos que regula as considerações de Aristóteles na Poética sobre as origens da tragédia parece ter influenciado fortemente Bacon e Galileu, assim como Hobbes e Descartes, no tocante à síntese, à imitação e ao reconhecimento necessários à instituição das ciências modernas. Basta observarmos como, no seu Novum Organun (bem como nos Ensaios e em outras obras filosóficas), Bacon apresenta seu moderno "método das descobertas" cientificas nos termos de uma "crítica dos ídolos" que remontaria diretamente ao teatro e à tragédia $(\mathrm{BACON}, 1984$, p. 21). O método trágico de "tradução e purificação" filosófica de Bacon, aplicado às fábulas e à mitologia greco-romana, poderia ensaiar uma "racionalização dos mitos" a partir dos elementos essenciais de uma "lógica da representação" ilustrada pelo modelo de tragédia retratada na Poética de Aristóteles. Esse método de racionalização dos mitos de Bacon parece ser análogo àquele do heliocentrismo copernicano defendido e difundido por Galileu. Racionalização essa dos mitos que parece ter regulado tanto a concepção mecanicista do homem em Descartes quanto a representação leviatânica do Estado civil em Hobbes, que entendem o homem e o Estado como artefatos. Eis a grande peripécia catártica da modernidade científica: o reconhecimento da Poética de Aristóteles como uma obra fundamentalmente filosófica e de cunho tanto teórico quanto prático.

Divergências conceituais entre autores modernos como Hobbes e Descartes, por exemplo, parecem retratar a disputa interpretativa sobre a tradução e a racionalização dos mitos ancestrais nos termos de diferentes derivações das línguas modernas: Galileu em italiano, Descartes em francês, Hobbes em inglês, por exemplo. Apesar das diferentes traduções e interpretações modernas da tradição greco-romana, dentro de uma modernidade heliocêntrica fomentada por Galileu, as filosofias de Hobbes e Descartes parecem convergir para alguns pontos em comum, particularmente no tocante a uma ressignificação criptografada do mito do Édipo. Em ambos os casos, o autoconhecimento de si dos homens é posto como princípio de conhecimento científico do mundo, do Estado e mesmo de Deus. Para Descartes (2004), o homem é considerado uma máquina, ou seja, um autômato confeccionado pelas mãos de um Deus criador. Em diversos momentos de suas obras filosóficas, quando de questões relacionadas à anatomia humana, as meditações cartesianas se assemelham a uma espécie autopsia conceitual do ser racional como uma espécie de máquina criada à imagem e semelhança de Deus. Autópsia filosófica essa na qual o homem é considerado um autômato movido e comovido pelos vapores 
do coração e pela circulação sanguínea, isto é, pelo movimento vital. Hobbes, por sua vez (logo na introdução do seu Leviatã, por exemplo) afirma que a vida é movimento e que as paixões são como o combustível que move e comove o corpo humano como um todo. Sob esse prisma mecanicista, assim como o homem cartesiano é entendido como uma criatura confeccionada pelas mãos divinas, para Hobbes o Estado civil seria uma espécie de homem-artificial confeccionado pelas mãos dos próprios homens. O fato é que, por influência do mecanicismo moderno heliocêntrico, tanto para Descartes (2004) quanto para Hobbes (1983), os homens e os cidadãos seriam máquinas ou autômatos programados naturalmente para se autoconservar sempre no movimento vital. O autoconhecimento de si dos homens, nesse registro moderno, possibilitaria o conhecimento ou o reconhecimento daqueles princípios de autoconservação do movimento que regularia todas as ações humanas em conformidade à geração de todas as coisas da natureza: o heliocentrismo característico da modernidade antropocêntrica do século XVII como medida de todas as coisas, inclusive do homem e do Estado.

Sob o prisma de uma crítica moderna à aristotelia medieval, o Novum Organun das ciências de Bacon (1984) parece ter mesmo inspirado muitos ensaios e experimentações filosóficas no período das grandes revoluções científicas. A interpretação dos filósofos modernos sobre a sistemática do Órgano de Aristóteles a partir da Poética, isto é, da síntese racional dos mitos, parece ter inspirado as fábulas conceituais de autores como Descartes e Hobbes, para não falar do heliocentrismo de Galileu. Esses filósofos teriam buscado na geometria euclidiana formas e imagens adequadas para se racionalizar conceitualmente as metáforas, as parábolas, as hipérboles e outras figuras de linguagem poética afins, no registro de um método científico caracteristicamente moderno e antropocêntrico. Essa racionalização geométrica dos mitos, advinda de uma restauração purificada da sabedoria dos antigos gregos e romanos, parece ter regulado não apenas as considerações de Galileu no campo da astronomia e de Bacon no campo da filosofia natural, mas também Descartes no campo da metafísica e Hobbes no campo da política. É nesse sentido que os elogios de Aristóteles à mitologia trágica do Édipo, tratado por ele sistematicamente em sua Poética (1999), parece ser de fundamental importância para se entender essa modernidade cientifica a partir de uma racionalização dos mitos. Lendo a si mesmos, como homens e como cidadãos, esses filósofos edipianos buscaram conhecer o cosmos, a natureza e a sociedade mediante uma leitura ensimesmada de suas próprias ideias, paixões e 
experiencias. "Conhece a ti mesmo", dizia a inscrição do templo de Apolo em Delfos. Inscrição ou máxima prática essa que, segundo Bacon (2002, p. 89), sintetizava a narrativa ancestral da bela fábula que colocava o sujeito racional moderno como agente de seu próprio conhecimento e destino.

Segundo Bacon, a Esfinge da fábula edipiana, criptografada na Poética de Aristóteles pela síntese de purificação dos mitos, deveria ser entendida pelos modernos como uma representação da própria ciência: uma quimera repleta de enigmas e paradoxos que devorava, com unhas e dentes afiados, o entendimento dos homens mais prudentes e sábios (2002, p. 88). Vencer a Esfinge ou solucionar seus enigmas, nesse registro trágico ou edipiano, equivaleria a ser senhor do seu próprio destino e do destino dos outros homens ${ }^{14}$. Essa interpretação da tragédia edipiana remonta diretamente à Poética aristotélica porque ali a tragédia do Édipo é considera o modelo de síntese crítica que envolveria tanto a teoria quanto a prática: "ensaios filosóficos". A síntese trágica representada pelo mito do Édipo seria o exemplo de como a arte poética poderia restaurar, na prática, a sabedoria dos antigos mediante uma atualização da potência dos mitos ancestrais. Atualização da potência mitológica essa que passaria por uma espécie de purificação, síntese ou redução ao essencial da matéria bruta advinda da cultura ancestral. Parece ter sido essa mesma inspiração esfíngica da razão apolínea, ilustrada por Bacon na atualização moderna da fábula do Édipo, que influenciou tanto Descartes (2004) quanto Hobbes (1983) a escreverem suas obras filosóficas tendo por base uma "leitura edipiana de si mesmos". Leitura edipiana essa que teria procurado colocar "o homem" como resposta para todas as questões esfíngicas impostas pela ciência moderna: "decifra-me ou te devoro".

A inspiração edipiana da Poética de Aristóteles na modernidade heliocêntrica parece ter sido tão catártica ${ }^{15}$ que chegou mesmo a regular as investigações de Descartes desde o início de suas Meditações. O método cartesiano, expresso também no Discurso sobre o método, parece mesmo regular os fundamentos da filosofia do autor segundo aquela máxima prática do templo

\footnotetext{
${ }^{14}$ O capítulo XXVIII da obra A sabedoria dos antigos, de Bacon (2002, p.88-90), é dedicado exclusivamente a explicar como uma racionalização da fábula da Esfinge ou do mito do Édipo poderia fundamentar princípios práticos de uma ciência moderna tanto natural quanto política.

${ }^{15}$ Sobre as implicações políticas, científicas e culturais do pensamento trágico na modernidade europeia, recomendo fortemente a leitura do livro de Eduardo Rinesi. Política e tragédia: Hamlet, entre Hobbes e Maquiavel.
} 
de Apolo em Delfos: nosce te ipsum ou "conhece a ti mesmo". Conhecendo a si mesmos de modo reflexivo e metódico, Descartes e Hobbes pensavam conhecer também o mundo e os demais homens iguais a e diferentes deles. No autoconhecimento do homem moderno, portanto, residiria a resposta para todos os fenômenos e indagações esfíngicas do conhecimento científico antigo e moderno: o conhecimento dos homens e do mundo reduzido à circunferência do umbigo dos homens mais civilizados. ${ }^{16}$ É por essa razão edipiana que Hobbes, no De Cive (2002), convoca os homens e os cidadãos a lerem a si mesmos e, depois, no Leviatã (1983), apresenta sua teoria mecanicista das paixões a partir daquela máxima apolínea do nosce te ipsum (que ele traduz como "leia a ti mesmo"). Essa razão edipiana e apolínea típica da modernidade teria sido colocada como princípio regulador de uma filosofia moderna tanto natural quanto política, para não dizer também religiosa

A atitude edipiana dos filósofos modernos tinha por finalidade minar a autoridade da igreja romana, fundada sobre a leitura de livros que somente os paredes e eclesiásticos tinham acesso. Essa modernidade filosófica compartilhada entre Descartes e Hobbes parece ter esse denominador comum: uma crítica filosófica à autoridade teológica da igreja romana fundada na leitura canônica de certos livros da filosofia aristotélica. Critica filosófica essa que diminuía a autoridade dos manuais canônicos sobre a filosofia e as ciências ao mesmo tempo em que convocava os homens a lerem mais a si mesmos. No autoconhecimento do homem residiria a resposta fundamental para todas as indagações esfíngicas da ciência moderna, uma vez que nele próprio se encerraria o princípio e o fim do conhecimento humano: os fenômenos naturais seriam apenas manifestações do movimento que aparecem para os sentidos e para o entendimento humano deste e daquele modo. O conhecimento da natureza e do mundo deveria passar por um tipo de conhecimento anterior do indivíduo sobre si mesmo como corpo natural, como homem e como cidadão.

Considerando o conhecimento dos fenômenos naturais e políticos como uma espécie

\footnotetext{
16 Bruno latur, em sua obra Jamais fomos modernos, (1994, p. 44) defende a tese de que a modernidade nunca teria se realizado de fato, uma vez que o movimento intelectual e político de emancipação do homem almejado pelos primeiros modernos jamais teria se concretizado, mas permanecido como legado. No registro de uma modernidade em constante processo de construção e atualização, Latur observa como o pensamento moderno teria consistido em um movimento de resgate, tradução e purificação de uma imensidade de perspectivas filosóficas pré-modernas que remontavam à antiguidade clássica; uma espécie de "racionalização da sabedoria dos antigos".
} 
de "reconhecimento" de si, os modernos entendiam que tanto a experiência particular quanto a vida social deveriam depender mais das ações dos próprios homens do que das intervenções divinas ou proféticas ${ }^{17}$. Além da síntese trágica da poética aristotélica, o mito do Édipo traria também para o debate moderno o legado parricida da Teogonia de Hesíodo, grafado na ancestralidade da sina familiar de Gaia, Urano e Cronos: o incesto, o parricídio e o domínio. A evocação da sina trágica do parricídio e do incesto, imanentes na mitologia do Édipo, passaria a ser fomentada pela modernidade cientifica como críticas às autoridades do papa e da madre igreja católica, respectivamente. Trata-se de um movimento de restauração mecânica do antigo projeto de criação ou de procriação familiar, no qual o filho cometeria o parricídio apenas para eliminar o pai carrasco e se apropriar de suas posses e domínio, inclusive da própria mãe. Essa sina parricida das origens incestuosas da família tradicional mitológica teria sido poeticamente narrada por Hesíodo ao retratar as origens dos deuses na Teogonia. A mesma sina ancestral de Hesíodo teria sido também retrata por Sófocles na tragédia do Édipo, porém de um modo que teria colocado o homem, e não mais os deuses, como princípio e fim de sua própria cultura e destino ${ }^{18}$.

Sob o prisma de uma racionalização dos mitos como representação ilustrada da própria ciência moderna, as críticas de Hobbes e de Descartes às indagações cientificas da Esfinge ancestral teriam tido mais ou menos a mesma resposta edipiana: "o homem", principio e fim do conhecimento humano do que quer que seja. No registro do heliocentrismo cosmológico e do antropocentrismo cientifico da época, que juntavam filosofia natural e política no registro da autoconservação dos corpos em movimento, a modernidade parece ter representado esse "homem edipiano" como uma espécie de máquina autorreplicante. Homem-máquina esse programado para se autoconservar automaticamente, inclusive fazendo a guerra generalizada ou constituindo um Estado civil soberano à sua imagem e semelhança. E parece ter sido esse um legado da

\footnotetext{
${ }^{17}$ O interesse de Aristóteles na Poética, sobretudo do capítulo 16 em diante (1999, p. 56) é que o reconhecimento seria a finalidade da tragédia ou da arte poética.

18 Sobre essa concepção da sina de Gaia na filosofia moderna e na política de Hobbes, publiquei um artigo intitulado: O mito das olimpíadas: Hesiodo, Bacon, Hobbes e a infindável luta dos titãs. (Prometeus: Filosofia em Revista. Catedra Unesco Akai, v. 9, ano 9, n. 20. UNB/UFS, Sergipe, 2016)
} 
modernidade científica à contemporaneidade, a saber, a representação do homem como uma espécie de máquina tanto no campo das ciências naturais quanto no campo da política. A rejeição moderna de uma natureza política do homem parece ter fundado as bases para a edificação de um Estado civil autômato que, uma vez embutido de poder soberano automático, estaria habilitado a fazer de tudo para se autoconservar. Sob o prisma do princípio de autoconservação dos homens reduzidos a peças e engrenagens de um tipo de Estado máquina e autômato, o legado hegemônico da tradição da filosofia política moderna só pode ser um modelo de vida também artificial. E esse parece ser um dos maiores desafios do pensamento antiautoritário da contemporaneidade, a saber, superar esse legado edipiano ancestral de uma continua atualização da máquina hereditária de produção e reprodução da vida artificial.

No registro dessas considerações sobre a histórica da filosofia política antiga e moderna, podemos dizer que os desafios contemporâneos das ciências que investigam o comportamento social dos homens exigem algum tipo de superação desse legado moderno que entende os homens e a natureza como máquinas e artefatos. Enquanto prevalecer tais concepções mecanicistas na filosofia e nas ciências estaremos fadados a sermos sempre peças de uma gigantesca engrenagem social produtora e reprodutora da vontade e da vida artificiais: simples massa em um faraônico projeto de engenharia social. Todavia, alertamos que a necessidade de se rejeitar o mecanicismo hereditário não significa resgatar aquela concepção naturalista da política e da teologia medieval ou aristotélica, por razões bélicas e religiosas que os modernos mesmo mostraram com suas críticas. Acredito que compete ao pensamento antiautoritário mais contemporâneo e futuro construir novos modos de vida social que superem essas antigas formas de organização familiar e política autorreplicantes. Sob esse prisma, imagino que o desafio maior da filosofia política contemporânea rumo ao novo milênio seja escapar do círculo vicioso dos pactos e contratos artificiais que tornam a representação política um ato mecânico automatizado. $\mathrm{O}$ recurso dos contratos e pactos convencionais que regulam a geometria da propriedade hereditária parece fazer o Estado civil ressurgir sempre atualizado como uma espécie de "máquina mortífera", capaz de se impor aos homens e à própria natureza, mesmo quando seu poder não seja de fato ilimitado ou absoluto. Pois, ainda que o Estado civil não venha a portar consigo um poder de fato absoluto e ilimitado (como defendem muitos liberais defensores dos poderes estatais limitados), o simples fato desse Estado portar consigo um direito de vida e de 
morte (vitae necisque potestas) sobre seus subordinados faz dessa autoridade civil um poder soberano análogo a um poder divino. Afinal, quem tem um poder de vida e de morte sobre alguém tem sobre esse indivíduo um poder absoluto e soberano, ainda que esse mesmo poder possa ser limitado frente a outros poderes ou potencias iguais ou ainda mais soberanas, incluindo o próprio Deus e a natureza. Acredito que as perspectivas filosóficas para o novo milênio deveriam pensar sim a política futura ainda no registro do constructo humano, porém sem resgatar com isso o contratualismo maquinal do legado hobbesiano ou o naturalismo hierárquico do legado aristotélico. Penso, por fim, que os desafios da filosofia política contemporânea presente e futura implicam no pensamento de novas perspectivas e práticas políticas que rejeitem o conservadorismo cultural da família tradicional e da propriedade hereditária que tanto o aristotelismo antigo quanto o contratualismo moderno parecem ter, cada qual ao seu modo e gosto, deixado como legado comum à posteridade filosófica.

\section{REFERÊNCIAS BIBLIOGRÁFICAS}

ARISTÓTELES. Poética e Política. In: “Coleção os pensadores”. Ed. Abril cultural, São Paulo, 1999.

ARISTÓTELES. Metafísica. Ed. Loyola, São Paulo, 2002.

BACON, F. A sabedoria dos antigos. Ed. UNESP, São Paulo, 2002.

BACON, F. Novum organum ou Verdadeiras indicações acerca da interpretação da natureza. In: “Coleção os pensadores”. Ed. Abril cultural, São Paulo, 1984.

DESCARTES, R. Meditações metafísicas. Editora Unicamp, Campinas, 2004.

DESCARTES, R. Discurso do método. Ed, Martins Fontes, São Paulo, 2009.

HOBBES, T. Leviatã ou matéria, forma e poder de um estado eclesiástico e civil. In: "Coleção os pensadores". Abril Cultural, São Paulo, 1983.

HOBBES, T Do cidadão. Ed. Martins Fontes, São Paulo, 2002.

HOBBES, T De corpore (parte 1 - “Cálculo ou lógica”). Editora Unicamp, Campinas, 2009.

HOBBES, T Elementos da filosofia (“Sobre o corpo”). Ed. Icone, São Paulo, 2012. 
LATUR, B. Jamais fomos modernos: ensaio de antropologia simétrica. Ed. 34, Rio de Janeiro, 1994.

LEBRUN, G. A Filosofia e sua História. Ed. Cosac Naify, São Paulo, 2006.

RINESI, E. Política e tragédia: Hamlet, entre Hobbes e Maquiavel. Ed, Beco do Arougue, Rio de Janeiro, 2009.

ROSSI, P. Os filósofos e as máquinas. Ed. Companhia das Letras, São Paulo, 1989.

Artigo recebido em: $15 / 10 / 20$

Artigo aprovado em: 14/12/20 